\title{
Correction: COCAINE CARDIOMYOPATHY - A CASE REPORT (2014, Vol 9, issue 3, p. 233-237.)
}

\author{
Georgiev Antonio, ${ }^{1}$ Zhivadinovik Julija ${ }^{2}$ \\ ${ }^{1}$ PHO Cardiology - Prima, MIT University, R. Macedonia \\ ${ }^{2}$ Institute of Anatomy, Medical Faculty, Skopje, University “Ss. Cyril and Metodius", R. Macedonia
}

In Sanamed Medical Journal, vol. 9, issue 3, in the text titled 'COCAINE CARDIOMYOPATHY - A CASE REPORT' authors made a mistake by inadequately citing parts of scientific paper, in sections Introduction and Discussion. The mistake was discovered by Center for Evaluation in Education and Science (CEON). Authors were informed from the Editorial Board of Medical Journal 'Sanamed' and the stated parts of paper were timely corrected.

Primljen/Received 01. 09. 2016. god.

Abstract: The second most commonly used drug in the world is cocaine. Its use is the most common cause of death among drug users. The use of cocaine is associated with acute and chronic complications. Mostly affected system in the human body's cardiovascular system. Cocaine cardiomyopathy may result from the use of cocaine.

This article presents a first case in Republic of Macedonia of 24-year-old male with reversible cocaine-related cardiomyopathy. Clinical presentation, laboratory, $\mathrm{X}$-ray, ultrasound findings and treatment are reviewed.

Key words: cocaine, reversible cocaine cardiomyopathy, diagnosis, treatment.

\section{INTRODUCTION}

Cocaine is an alkaloid extract obtained from the leaves of the plant Erythroxylon coca. This plant usually grows in South America and has a data on its use before 5000 years. This drug and its complications are a worldwide problem. Cocaine is the most frequent cause of drug related deaths. Very useful data are obtained from a European retrospective study done on 479 ACS patients. The current study included subjects younger than 50 years admitted to a critical care unit from 2001 to 2008. From the total number of participants involved, 24 patients $(5 \%)$ had admitted to recent cocaine abuse or tested positive on urine drug screening (1). In 2005 registered 2.4 million persons were actively using cocaine. Verified that the most frequent users of cocaine as a drug are young people aged 18 to 25
Prihvaćen/Accepted 01. 10. 2016. god.

years and it is estimated that $11 \%$ of the population has used it at some point (2). The ratio of men to women is $2: 1$. The 2008 National Survey on Drug Use and Health reported that approximately 36.8 million Americans aged 12 years and older (14.7\% of Americans in that age group) had tried cocaine at least once (3). The trade with this illicit drug in Republic of Macedonia is prosecuted by law. Yet there are people who use this drug and have complications from it.

Cocaine may be used by smoking, intravenous, gastrointestinal and nasal inhalation. It causes physiological changes highlighted, psychological effects but also addictive. Mechanism of action of cocaine is not completely understood. It is assumed that its detrimental effect is due to its direct toxicity. But also because of his mighty sympathomimetic action which is the main characteristic of cocaine. With sympathetic acting cocaine increases level of norepinephrine, dopamine and catecholamines, with the suitable effect on the systems in the body, particularly the cardiovascular system (tachycardia, arrhythmia, hypertension...). Cocaine also acts on muscarinic receptors blocking the reuptake of dopamine and serotonin which contributes to the appearance of "positive psychological effects". Cocaine carried blocking sodium ion channels on myocytes and contributing to the occurrence of cardiac arrhythmias $(1,4,5)$.

Symptomatology in cocaine intoxication is associated with adrenergic redundancy that causes cocaine. The occurrence of hypertension is one of the most common symptoms. Impaired mental condition of the users on this drug manifested by the appearance of acute delirium or 
mania (2). Very often cocaine users admitted to hospital with already manifested complications. Complications of cocaine can be acute or chronic. Cocaine related complications can affect any system: cardiac (coronary artery spasm, myocardial infarction, hypertension, cocaine cardiomyopathy, myocarditis, arrhythmia, possible occurrence of endocarditis, acceleration of atherosclerosis); vascular (aortic dissection and rupture, vasculitis, superficial and deep venous thrombosis, thrombophlebitis); neurological (cerebral infarction or hemorrhage, transient ischemic attack, seizures, migraine); gastrointestinal (ulcer disease, mesenteric thrombosis, perforation); pulmonary (pneumonia, pulmonary oedema, occurrence of haemoptysis); obstetric (abruptio placentae, spontaneous abortion, prematurity, growth retardation) (2-7)...

\section{CASE REPORT}

We present a case of a twenty four years old male, with a history of inhaling vaporized cocaine, and marihuana for two years. The main complaints of patient were fatigue, labored respiration, especially et night, dyspnea, anxiety, increased heart rate and lost of appetite during last 2-3 months. The patient was conscious, anxious, oriented to time, space and persons. Heart sounds were clear with systolic murmur. The ECG showed sinus tachycardia (HR > 100/min) (Figure 1) and about 0,5 mm upsloping ST segment depression in lateral leads. Blood pressure was elevated $(150 / 105 \mathrm{mmHg})$. Laboratory analysis showed elevation of blood Urea (10.6 $\mathrm{mmol} / \mathrm{L})$, Creatinine (154 mmol/L), Na (149 mEq/L), K $(4.2 \mathrm{mEq} / \mathrm{L})$ and iron-deficiency anemia with $\mathrm{Fe}(7.1$ $\mathrm{mcg} / \mathrm{dl})$. X-ray findings obtained enlarged heart silhouette (Figure 2). Echocardiographic evaluation showed left chamber dilatation with reduced global systolic function and ejection fraction (EF) 38\%, designated mitral cusps with posterior cusp prolapsed, thin regurgitated flow and intraatrial septum tissue changes.

Preceding therapy Carvedilol and Aspirin was changed to heart failure - guideline-based heart failure therapy: Carvedilol, nonselective alfa/beta - adrenergic blocker (2 x 6, 25 mg per day), Perindopril, ACE inhibitor (4 mg per day), Spironolactone, mineral corticoid receptor antagonist, MRA (25 mg per day), Thiazide diuretic (25 mg per day) and Aspirin, acetylsalicylic acid (100 mg per

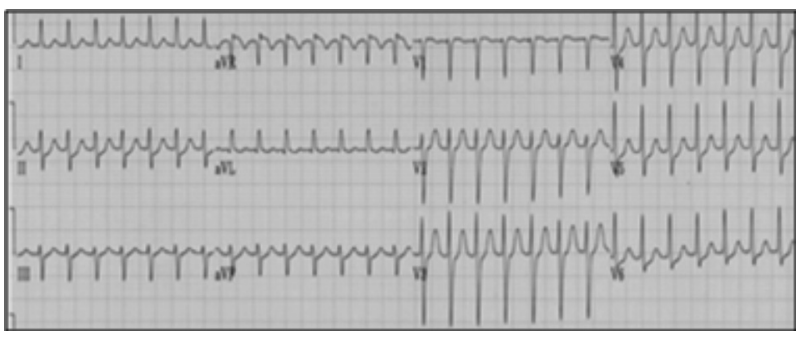

Figure 1. ECG findings

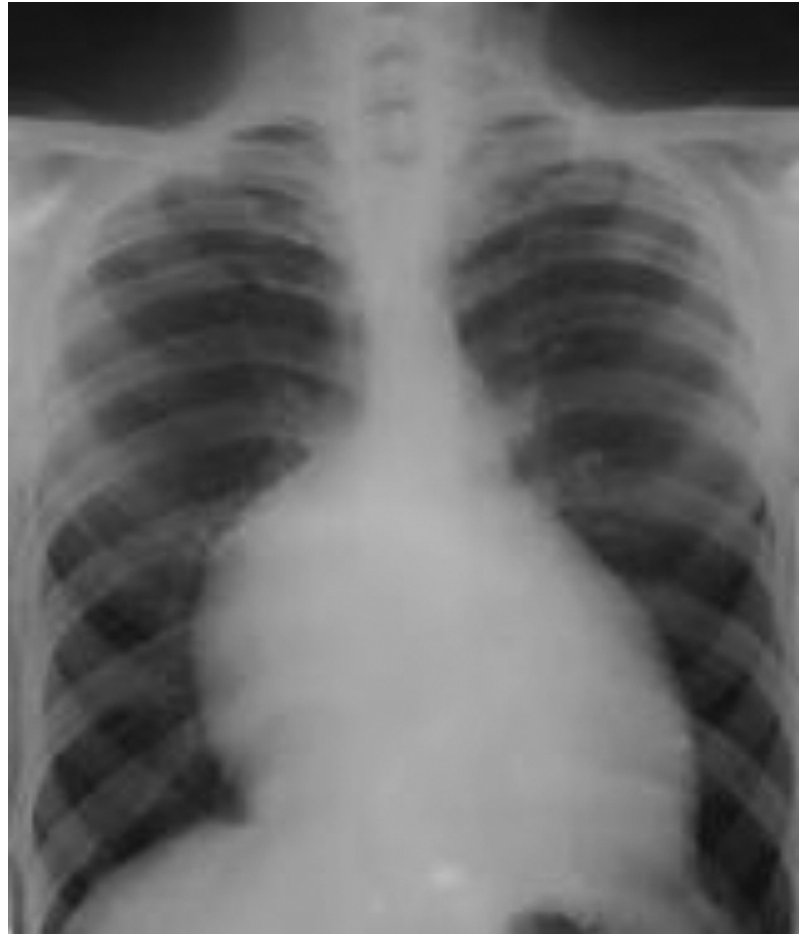

Figure 2. X-ray findings of enlarged heart silhouette

day). Therapy for correction of anemic syndrome was recommended. Cocaine cessation was obligated.

Two months later, after cocaine cessation and treatment in specialized hospital, the patient didn't fill the symptoms from the first examination, but he was at bad physical condition. Laboratory findings were normalized: Urea $7.6 \mathrm{mmol} / \mathrm{L}$; Creatinin $108 \mathrm{mmol} / \mathrm{L}$; Na 139 $\mathrm{mEq} / \mathrm{L}$; K $4.2 \mathrm{mEq} / \mathrm{L}$ and Fe $16.2 \mathrm{mcg} / \mathrm{dl}$. EKG showed sinus rhythm with HR $65 / \mathrm{min}$. Blood pressure was 120/80 mm Hg. Dimensions of left ventricle were in referent values. Left ventricle function was slightly reduced with EF 49\%, mitral cusps were designated with posterior cusp prolapsed and intraatrial septum tissue changes. The patient continued with the same therapy.

The patient abstained from cocaine use and five months later he didn't fill any of the symptoms from the first examination, and he was et good physical condition. Laboratory findings were in the ranges of referent values. Left and right ventricles function and dimensions were preserved. Left ventricle EF was 62\%. The patient continued with medications: Nebivolol, cardioselective âl- receptor blocker (2,5 mg per day) and Aspirin (100 mg per day).

\section{DISCUSSION}

This is the first case of cocaine reversible cardiomyopathy registered at the Clinic for Cardiology in Macedonia. Patients who are addicted to drugs are difficult for cooperation. This medical case demanded great personal and professional effort. 
Among cocaine users certainly dominated symptoms of the cardiovascular system. Symptoms resulting from hypertension, angina pectoris, also these patients can be hospitalized with symptoms of myocardial infarction or dissection of the aorta. Other symptoms from the vascular origin may occur in cerebral ischemia or hemorrhage. Cocaine leads to damage of cardiac myocytes, leading to the emergence of cardiomyopathy. Often these patients are with signs of congestive heart failure. So, the first clinical symptoms in these patients may arise as a result of acute cardiac decompensation with or without pulmonary edema. Hypotension and shock make investigations and treatment in these patients very demanding. It is not uncommon for these patients their first hospitalization to finish lethal. Cocaine is the most common cause of sudden death caused by drugs $(1,4,7,8,9)$.

In our case, which is very rare in the literature, we refer for the 24 year old boy who at first medical examination was with signs of congestive heart failure, hypertension, iron-deficiency anemia and elevated electrolyte and degradation products. First echocardiography evaluation showed reduced global systolic function with $\mathrm{EF}$ $38 \%$. After five months of using the appropriate therapy and complete renunciation of the use of cocaine, on control echocardiography evaluation showed completely normalization of cardiac left ventricular function with $62 \% \mathrm{EF}$ and the full normalization of the general condition and laboratory analysis. This represents the classical case of reversible cocaine-related cardiomyopathy.

In the absence of prospective randomized studies the literature data obtained mainly from case reports or from autopsy studies. Saurabh K. Chokshi et al. in their case report also refer for reversible cocaine-related cardiomyopathy. In their case it is a woman, 35 years old, which is also completely withdrawn clinical signs of cardiac decompensation, with normalization of the findings of all investigations. In this case endomyocardial biopsy was done and it was not found any fibrosis, necrosis or inflammatory infiltrate (10).

Virmani et al. in their study included autopsies of 40 patients, 31 of whom died cocaine-related deaths and 9 of whom were homicide victims with detectable blood cocaine levels. In this study, in $20 \%$ of respondents has been established the existence of a myocarditis proven with toxicology screen laboratory tests (11). In another autopsy study, Tazelaar et all., refers for finding of myocardial necrosis very similar to the findings in pheochromocytoma (12).

Robledo-Carmona at all. in their case report refers for severe cardiomyopathy associated to cocaine abuse. Histological findings, in this case, of the left ventricular myocardium indicate the presence of mononuclear infiltrates, degenerative changes, present necrotic changes on myocytes and also distinctly marked and severe form of fibrosis in interstitial space (13).

While most cases of cocaine-related cardiomyopathy have proved to be reversible, others have resulted in permanent cardiac dysfunction or death. Any patient with the data that used cocaine and clinical signs of congestive heart failure should make us suspicious and induce as on cocaine-related cardiomyopathy etiological basis. This especially refers to a younger patient, a smoker with signs of adrenergic excess $(5,10)$.

If there is doubt about cocaine cardiomyopathy first need to make laboratory investigations: urine toxicology screen for cocaine and its metabolites, also might expect electrolytes abnormalities ( $\mathrm{Na}, \mathrm{K})$, anemic syndrome and a rise of renal degradation products (blood urea nitrogen and creatinine), blood tests for possible infection.

Radiographic analysis mostly shows a picture of cardiomegaly and congestive heart failure. But for most cocaine addicts radiographic analysis is often normal.

Echocardiography evaluation shows reduced global systolic function with chamber dilatation. In cocaine addicts who had myocardial infarction we can expect echocardiographic finding of impaired (hypo/akinesia) regional mobility on the wall of the chamber.

Cocaine addicts often have angina symptoms and they are indicated to make angiography. Coronary angiography is usually with normal finding on coronary arteries or with insignificant changes.

In cases of cocaine cardiomyopathy mostly have no specific ECG changes. In these patients are also possible nonspecific ST-T wave changes, ECG signs of left ventricular hypertrophy and the occurrence of arrhythmias. Unpredictable possible ECG changes especially malignant arrhythmias suggest a need for constant monitoring of these patients.

\section{Management}

Associations of cardiologists donžt have recommendations for concrete medicamentous treatment of cocaine cardiomyopathy (1). Medical treatment of these patients is similar to the recommendations for treatment of patients with other forms of dilated cardiomyopathy. Certainly in the first line beta-blockers should be included in these patients with cocaine-related heart failure. Cocaine addicts are usually in adrenergic excess and ordination of benzodiazepines for them is recommended. In the event of complications in these patients should be adequately reacting. So, in developing a shock should be given vasopressors and inotropic drugs. The occurrence of arrhythmias especially malignant nature the need to react quickly by giving antiarrhythmics is crucial. Cardioversion is used if there is no effect from drug 
conversion of arrhythmias. These patients requires continuous monitoring and in case of apnea to perform endotracheal intubation by connecting the respirator (mechanical ventilation). In cases where angina symptoms are accompanied by ST segment changes on ECG, besides the right drug treatment (beta-blockers, nitrates, calcium channel blocking medicaments), coronary angiography should be performed. It is not uncommon for these patients to survive the myocardial infarction $(1,4$, $14,15)$. For the purposes of this, these patients need to know and to be familiar with the medical practice of cardiac magnetic resonance as a method that is quite useful for predictions of reversibility of cocaine-induced ventricular dysfunction (16).

John McMurray et al. ESC Guidelines for the diagnosis and treatment of acute and chronic heart failure 2012 (17) recommend the following therapy:

The combination of beta blockers with ACE inhibitors used in the treatment of patients with cardiomyopathy and left ventricular EF $<40 \%$. This combination of drugs is used to reduce the risk of heart failure hospitalization and the risk of premature death. An MRA is recommended for all patients with left ventricular $\mathrm{EF}<35 \%$ and persisting symptoms despite medicament treatment. It is good to mention that analysis of B-type natriuretic peptide (BNP) level can help monitor the presence of congestive heart failure. Also BNP is very helpful to monitor response to treatment (17).

Most of reported cases with cocaine cardiomyopathy showed that treatment of these patients depends on stopping of drug use. Patients who stopped using drugs have registered significant improvements of the condition of cocaine-related cardiomyopathy. There are cases, as in our patient in this case report, when we have a full reversibility of cocaine cardiomyopathy and the establishment of completely normal cardiac function. But if these patients start using drugs again, the possibility reoccurrence of cocaine-related cardiomyopathy is confirmed most of the cases described in the literature (4).

Physicians usually don't consider the possibility of cocaine use of their patients. It is therefore necessary to inform and educate them. Abstinence from cocaine use and long time follow up is mandatory in these patients. The regular echocardiographic controls are necessary. The patient needs to take care of the other risk factors such as hypertension, smoking and others. In planning the treatment of these patients of great importance is ambulatory treatment of addiction. Also there is a need for hospitalization centers when it is necessary for their detoxification.

\section{CONCLUSION}

This is the first publication of cocaine-related cardiomyopathy in our country. Recognition of cocaine cardiomyopathy is crucial for optimal treatment. It requires a structured education of drug users about the consequences, risks of using cocaine and "Life benefit". It requires a multidisciplinary approach in treating these individuals and it should include the family, but also a psychiatrist, psychologist, sociologist, cardiologist and other professional disciplines.
Abbreviations
ACE - Angiotensin converting enzyme
BNP - Natriuretic peptide
BUN - Blood urea nitrogen
ECG - Electrocardiography
$\mathbf{E F}$ - Ejection fraction
ESC - European Society of Cardiology
HR - Heart rate
MI - Myocardial infarction
MRA - Mineral corticoid receptor antagonist
ST - ECG between the end of the S wave (the J point) and the beginning of the $T$ wave

\title{
Sažetak
}

\section{KOKAINSKA KARDIOMIOPATIJA — PRIKAZ SLUČAJA}

\author{
Georgiev Antonio, ${ }^{1}$ Zhivadinovik Julija ${ }^{2}$ \\ ${ }^{1}$ PZO Kardiologija — Prima, MIT Univerzitet, Skoplje, R Makedonija \\ 2 Institut za anatomiju, Univerzitet "Sv. Ćirilo i Metodije", Medicinski fakultet, Skoplje, R Makedonija
}

Kokain je druga najčešće korišćena droga u svetu. Upotreba ove droge je najčešći uzrok smrti kod korisnika droge. Upotreba kokaina daje akutne i hronične komplikacije. Najčešće afektirani sistem u ćovekovom organizmu je kardiovaskularni sistem. Kokainska kardiomiopatija može biti izazvana konzumiranjem kokaina.
Ovaj članak predstavlja slučaj dvadesetčetvorogodišnjeg muškarca s reverzibilnom kokainskom kardiomiopatijom, što predstavlja prvi takav u Republici Makedoniji. Nalazi kliničkog pregleda, laboratorijskih analiza, rendgengrafije srca i pluća, ultrazvuka srca i tretman su prikazani.

Ključne reči: kokain, reverzibilna kokainska kardiomiopatija, dijagnoza, lečenje. 


\section{REFERENCES}

1. Finkel JB, Marhefka GD. Rethinking cocaine-associated chest pain and acute coronary syndromes. Mayo Clin Proc. 2011; 86(12): 1198-207.

2. Egred M, Davis GK. Cocaine and the heart. Postgrad Med J. 2005; 81(959): 568-71.

3. SAMHSA - Substance abuse and mental health service administration. Sharp decline also continues for methamphetamine use. US Department of Health and Human Services (DHS); Office of Applied Studies Results from the $2008 \mathrm{Na}-$ tional Survey on Drug Use and Health: National Findings. http://oas.samhsa.gov/nsduh/2k8nsduh/2k8Results.cfm. 2009.

4. Schwartz BG, Rezkalla S, Kloner RA. Cardiovascular effects of cocaine. Circulation. 2010; 122(24): 2558-69.

5. Howell LL, Kimmel HL. Monoamine transporters and psychostimulant addiction. Biochem Pharmacol. 2008; 75(1): 196-217.

6. Phillips K, Luk A, Soor GS, Abraham JR, Leong S, Butany J. Cocaine cardiotoxicity: a review of the pathophysiology, pathology, and treatment options. Am J Cardiovasc Drugs. 2009; 9(3): 177-96.

7. Awtry EH, Philippides GJ. Alcoholic and cocaine-associated cardiomyopathies. Prog Cardiovasc Dis. 2010; 52(4): 289-99.

8. Bhargava S, Arora RR. Cocaine and cardiovascular complications. Am J Ther. 2011; 18(4): e95-e100.

9. Velasquez EM, Anand RC, Newman WP 3rd, Richard SS, Glancy DL. Cardiovascular complications associated with cocaine use. J La State Med Soc. 2004; 156(6): 302-10.
10. Chokshi SK, Moore R, Pandian NG, Isner JM. Reversible cardiomyopathy associated with cocaine intoxication. Ann Intern Med. 1989; 111(12): 1039-40.

11. Virmani R, Robinowitz M, Smialek JE, Smyth DF. Cardiovascular effects of cocaine: an autopsy study of 40 patients. Am Heart J. 1988; 115(5): 1068-76.

12. Tazelaar HD, Karch SB, Stephens BG, Billingham ME. Cocaine and the heart. Hum Pathol. 1987; 18(2): 195-9.

13. Robledo-Carmona J, Ortega-Jimenez MV, Garcia-Pinilla JM, Cabra B, de Teresa E. Severe cardiomyopathy associated to cocaine abuse. Int J Cardiol. 2006; 112(1): 130-1.

14. Rangel C, Shu RG, Lazar LD, Vittinghoff E, Hsue PY, Marcus GM. Beta-blockers for chest pain associated with recent cocaine use. Arch Intern Med. 2010; 170(10): 874-9.

15. Littmann L, Narveson SY, Fesel MN, Marconi SL. Beta blocker treatment of heart failure patients with ongoing cocaine use. Int J Cardiol. 2013; 168 (3): 2919-20.

16. Smedema JP. Cardiac magnetic resonance predicts reversibility of cocaine-induced ventricular dysfunction. Cardiovasc J Afr. 2009; 20(3): 198-9.

17. McMurray JJ, Adamopoulos S, Anker SD, et al. ESC Guidelines for the diagnosis and treatment of acute and chronic heart failure 2012: The Task Force for the Diagnosis and Treatment of Acute and Chronic Heart Failure 2012 of the European Society of Cardiology. Developed in collaboration with the Heart Failure Association (HFA) of the ESC. Eur Heart J. 2012; 33(14): 1787-847.

\section{Correspondence to /Autor za korespondenciju}

Georgiev Antonio

University Clinic for Cardiology

Vodnjanska bb

1000 Skopje, Republic of Macedonia

e-mail: antoniogeorgiev@yahoo.com

tel: 0038970305114 